\title{
Does eosinophilia and neutrophil to lymphocyte ratio affect hospital re-admission in cases of COPD exacerbation?
}

\author{
Meltem ÇOBAN AĞCA ${ }^{1}$ \\ Emine AKSOY ${ }^{1}$ \\ Dildar DUMAN ${ }^{1}$ \\ Ipek ÖZMEN ${ }^{1}$ \\ Elif YILDIRIM ${ }^{1}$ \\ Sinem GÜNGÖR ${ }^{1}$ \\ Nagihan DURMUŞ ${ }^{1}$ \\ Ülkü AKA AKTÜRK ${ }^{1}$ \\ Cüneyt SALTÜRK ${ }^{2}$ \\ Fatma Merve TEPETAM ${ }^{3}$ \\ Zuhal KARAKURT $^{1}$
}

${ }^{1}$ Clinic of Chest Diseases, Istanbul Sureyyapasa Chest Disesases and Chest Surgery Training and Research Hospital, Istanbul, Turkey

1 Istanbul Süreyyapaşa Gögüs Hastalıkları ve Gögüus Cerrahisi Eğitim ve Araştırma Hastanesi, Göğüs Hastalıkları Kliniği, İstanbul, Türkiye

2 Intensive Care Unit, Istanbul Sureyyapasa Chest Disesases and Chest Surgery Training and Research Hospital, Istanbul, Turkey

2 istanbul Süreyyapaşa Göğüs Hastalıkları ve Gögüs Cerrahisi Ĕ̆itim ve Araştırma Hastanesi, Yoğun Bakım Ünitesi, İstanbul, Türkiye

${ }^{3}$ Clinic of Immunology and Allergy, Istanbul Sureyyapasa Chest Disesases and Chest Surgery Training and Research Hospital, Istanbul, Turkey

3 istanbul Süreyyapaşa Göğüs Hastalıkları ve Göğüs Cerrahisi Ĕ̆gitim ve Araştırma Hastanesi, Immünoloji ve Allerji Kliniği, İstanbul, Türkiye

\section{SUMMARY}

Does eosinophilia and neutrophil to lymphocyte ratio affect hospital re-admission in cases of COPD exacerbation?

Introduction: We aimed to assess the relationship between peripheral eosinophilia and neutrophil/lymphocyte ratio with hospital admissions and re-admissions with chronic obstructive pulmonary disease (COPD) exacerbations.

Materials and Methods: An observational cohort study was carried out in a tertiary teaching hospital. Subjects with previously diagnosed COPD and who were admitted as outpatients with acute exacerbations were included. The subjects' characteristics, complete blood count (CBC) parameters, neutrophil to lymphocyte rate (NLR), C-reactive protein (CRP), mean platelet volume (MPV) on admission and re-admission within the first 28 days. Patients were grouped according to their peripheral blood eosinophilia levels; group 1, > 2\% (eosinophilic), group $2, \leq 2 \%$ (non-eosinophilic or neutrophilic). The recorded data from the two groups were compared.

Results: 1490 eligible COPD subjects were enrolled. Approximately 42\% were classified as eosinophilic. The non-eosinophilic group had a significantly higher leukocyte count, neutrophil percentage, and NLR than the eosinophilic group. The NLR value in patients with repeat re-admissions was higher than the average, i.e., $4.50(p=0.001)$. MPV and CRP measured on admission and re-admission were similar in both groups. The rate of hospital re-admission within 28 days was significantly higher in patients with a noneosinophilic attack.

Conclusion: When a patient is admitted to outpatients with a NLR greater than 4.50 and with a non-eosinophilic exacerbation they have an increased risk of re-admission in the first month. Higher $N L R$ values and non-eosinophilic exacerbations may be helpful for the early detection of potential acute attacks in COPD patients, and may be indicators for antibiotic management.

Key words: Chronic obstructive pulmonary disease, COPD exacerbation, peripheral eosinophilia, neutrophil to lymphocyte ratio

\section{Yazışma Adresi (Address for Correspondence)}

Dr. Meltem ÇOBAN AĞCA

İstanbul Süreyyapaşa Göğüs Hastalıkları ve Göğüs Cerrahisi Eğitim ve Araştırma Hastanesi, Göğüs Hastalıkları Kliniği,

ISTANBUL - TURKEY

e-mail: agcameltem@yahoo.com 


\section{ÖZET}

\section{KOAH alevlenmesinde eozinofil ve nötrofil/lenfosit oranı hastaneye tekrar başvuruyu etkiler mi?}

Giriş: Bu çalışmada kronik obstrüktif akciğer hastalığı (KOAH) olanların alevlenme ile hastane başvurularında ve tekrar hastane başvurusunda, periferik eozinofili ile nötrofil/lenfosit oranı (NLO)arasındaki ilişki araştırıldı.

Materyal ve Metod: Gözlemsel-kohort çalışma üçüncü basamak eğitim ve araştırma hastanesinde yapıldı. Hastalar daha önceden KOAH tanısı alan, ayaktan alevlenme ile hastane başvurusu olanlar arasından seçildi. Hastaların ayaktan hastane başvusunda ve ilk 28 gün içinde olan tekrar başvurusunda tam kan sayımı, nötrofil/lenfosit oranı (NLO), C-reaktif protein (CRP), ortalama trombosit hacmi (MPV) değerlerine bakıldı. Periferik eozinofili değerlerine göre hastalar, grup 1; > \%2 (eozinofilik), grup 2; $1 \% 2$ (eozinofilik olmayan veya nötrofilik) olarak gruplandırıldı. Kaydedilen veriler iki grup arasında karşılaştırıldı.

Bulgular: Çalışmaya uygun 1490 hasta alındı. Hastaların yaklaşık olarak \%42'si eozinofilik idi. Eozinofilik olmayan grupta, eozinofilik gruba göre lökosit sayıII, nötrofil yüzdesi ve NLO değeri önemli derecede yüksekti. NLO, tekrar hastane başvurusunda ortalamadan yüksek (4.50, $p=0.001)$ idi. MPV ve CRP başvuruda ve tekrar başvuruda iki grup arasında benzerdi. Eozinofilik olmayan grupta, hastaneye ilk 28 günde tekrar başvuru oranı önemli derecede yüksekti.

Sonuç: Ayaktan başvuran eozinofilik olmayan ataklarda, NLO oranı 4.50 üzerinde ise ilk 1 ay içinde tekrar hastane başvuru riski artmaktadır. Yüksek NLO ve eozinofilik olmayan alevlenme, KOAH alevlenmesinin erken tanınması için ve tedavide antibiyotik başlanması için yardımcı olabilir.

Anahtar kelimeler: Periferik eozinofili, nötrofil/lenfosit oranı, KOAH alevlenme

\section{INTRODUCTION}

In chronic obstructive pulmonary disease (COPD), exacerbations are observed 1-3 times per year despite optimal medical treatment (1). Acute exacerbations adversely affect the prognosis of the disease and increase morbidity and mortality (2). Prevention, early detection, and prompt treatment of exacerbations are vital to reduce the burden of COPD (3).

A different number and type of inflammatory cells are known to play a role in exacerbations of COPD (4). Pathogenesis of inflammation with increased neutrophils, macrophages and $\mathrm{T}$ lymphocytes are mostly seen, but an increase in eosinophils is seen in $25-30 \%$ (5). Peripheral eosinophilia is thought to be a result of the inflammatory process of COPD exacerbation (6). As a result of these differences in the inflammation of the disease, progression is not the same in all patients.

There are a small number of studies that point to the treatment modality being determined by the type of inflammation, whether it be eosinophilic (> $2 \%$ eosinophils) or non-eosinophilic $(\leq 2 \%$ eosinophils $)$ $(7,8)$. Accordingly, there is a reportedly better response to corticosteroid treatment in the case of a high percentage of eosinophils in sputum samples and bronchial tissue in COPD exacerbations. Severe exacerbations are reported to improve by reducing eosinophilic inflammation (9).

In recent years, various studies have investigated neutrophil/lymphocyte ratio (NLR), mean platelet volume (MPV), and platelet to mean platelet volume ratio (PLT/MPV) as novel inflammatory markers associated with oncological and cardiological diseases $(10,11)$. These markers have been shown to significantly increase in lung diseases such as sarcoidosis, pulmonary embolism, and cancer (12-14). A small number of studies reported that NLR is increased in COPD and this increase has an effect on mortality $(15,16)$.

There are few studies that have looked at re-admission in patients with COPD relative to the type of inflammation during an exacerbation (i.e., eosinophilic vs. non-eosinophilic) (4-7).

In this study, we aimed to assess what effect peripheral blood eosinophilia, in association with NLR, MPV, PLT/MPV, and C-reactive protein (CRP), has on outpatients with COPD exacerbations. We also aimed to determine whether there was a difference in re-admission within the first 28 days following a COPD exacerbation between the eosinophilic and the non-eosinophilic group, relative to NLR.

\section{MATERIALS and METHODS}

This observational, retrospective cohort study was conducted in a tertiary education research hospital from the $1^{\text {st }}$ January 2014 to the $31^{\text {st }}$ December 2014. The study was approved by the local ethics committee of the hospital. Ethical approval was in accordance with the Declaration of Helsinki. As all data was obtained retrospectively from the hospital database no consent was obtained. 


\section{Patients}

All patients admitted to the outpatient and emergency department of the pulmonary diseases hospital with an acute exacerbation, and who were previously diagnosed with COPD by a specialist pulmonologist over a 40 year period and assigned one of the ICD 10 (International Classification of Diseases) codes, J44, J44.0, J44.1, J44.8, and J44.9, were included. The patients included in the study are shown in the flow chart in Figure 1. In patients with more than one diagnosis code diagnosis of J44 and sub-segment of the condition being must be.

\section{Definitions}

COPD: The diagnosis of COPD was based on a compatible history and spirometry, a postbronchodilator $\mathrm{FEV}_{1}$ /forced vital capacity ratio of $70 \%$, or less, and an $\mathrm{FEV}_{1}$ and forced vital capacity ratio of $70 \%$, or less (17). As spirometry test data were not available on the online system, these data were recorded from the subjects' charts.

COPD exacerbation: The exacerbation of COPD is an acute change in a patient's baseline dyspnea, cough, or sputum that is beyond normal variability, and that is sufficient to warrant a change in therapy (18).

\section{ICD codes}

Reasons for COPD exacerbation: Infections: For a definition of an infection-induced exacerbation of COPD, subjects must meet the Anthonisen criteria for shortness of breath, increased sputum purulence and sputum volume, and must be classified as $\mathbf{J 4 4 . 0}$ or J44.1 by ICD coding (19). Other causes: Other causes of COPD exacerbations as defined by the ICD coding system are arrhythmias (147, 148, 149, 149.8, 149.9),

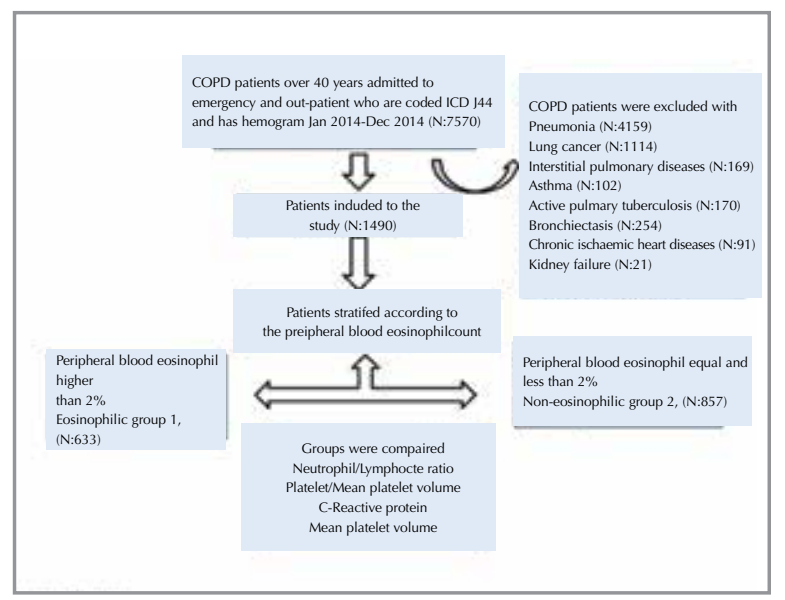

Figure 1. Flow chart of the patients. heart failure (150, 150.0, 150.9), pleurisy (J91, J94.8, J94.9), pneumothorax (J93.1, J93.8), and pulmonary embolism (I26, I26.0, I26.9).

Ineligible patient groups: COPD patients with pneumonia, lung cancer, interstitial lung disease, asthma, bronchiectasis, tuberculosis, angina pectoris, myocardial infarction, and renal impairment were excluded.

Peripheral eosinophilia: Patients were grouped according to their peripheral blood eosinophil count, i.e. group $1>2 \%$ and group $2 \leq 2 \%$ (20) (Figure 1 ).

Neutrophil to lymphocyte ratio (NLR): NLR has been studied as a novel marker of inflammation. NLR is determined by dividing the absolute neutrophil count by the number of lymphocytes in the total blood count (21).

Mean platelet volume (MPV): MPV is an early marker of platelet activation during inflammation and thrombocytosis. An abnormal platelet count may be an important marker indicating a systemic inflammatory response (22). PLT/MPV was calculated as the ratio of mean platelet volume and platelet count.

Outpatient readmission: This was defined as hospital re-admission within 28 days of the initial admission to the chest diseases outpatient or emergency department.

Co-morbid diseases: Diabetes mellitus, heart failure, chronic ischemic heart disease, arrhythmia, and hypertension.

\section{Measurements}

Patient information was obtained from the hospital database: age, gender, ICD-10 code, blood count, biochemistry, and CRP results at the time of admission to the hospital were recorded. Using this data the white blood cell count (WBC), neutrophil count, lymphocyte count, peripheral blood eosinophil count, eosinophil percentage, NLR, MPV, and PLT/MPV ratio were evaluated. WBC, neutrophil, lymphocyte and platelet counts and MPV were determined using a Coulter LH 780 Hematology Analyzer (Beckman Coulter, USA). CRP was checked by the nephelometry method using a BN II System with a Siemens (Germany). The normal range of CRP is $0-5 \mathrm{mg} / \mathrm{L}$.

According to the number of peripheral blood eosinophils patients were divided into two groups. Peripheral eosinophilia, defined by an eosinophil count higher than $2 \%$ was accepted as an eosinophilic COPD exacerbation (group 1). A peripheral blood eosinophil count equal or less than $2 \%$ was defined as 
a non-eosinophilic COPD exacerbation (group 2). The groups were compared with the data recorded.

The same inflammatory values (WBC, NLR, MPV, PLT/ $M P V$, and CRP) were recorded on re-admission within the first 28 days. The eosinophilic and non-eosinophilic groups were compared with respect to their inflammatory markers and re-admission rates. Pulmonary function tests and sputum examinations were not available from the hospital database.

\section{Statistical Analysis}

A descriptive analysis was used to investigate the subject demographics and hospital data. Groups were compared using the Mann-Whitney $U$ tests for continuous variables and the non-parametric or the parametric Student's t-test for continuous variables. The chi-square test was employed for dichotomous variables. The median with interquartile range (IQR) was employed for non-parametric continuous variables, and mean \pm standard deviation $(\mathrm{SD})$ was used for parametric continuous variables. Count and percentage were used when applicable. A p value $<$ 0.05 was accepted as statistically significant. Hospital re-admissions within one month relative to the use of steroids was compared between the two groups with the chi-square test.

\section{RESULTS}

Twenty percent of 7450 patients admitted with a diagnosis of COPD exacerbation were enrolled in the study. A total of 1490 patients were assessed and these included 633 patients with eosinophilic COPD (group 1 , peripheral blood eosinophils $>2 \%$ ), and 857 patients with non-eosinophilic COPD (group 2, peripheral blood eosinophils $\leq 2 \%$ ). The eosinophilic group included $42 \%$ of all patients (Figure 1 ). In both groups, there were more men than women, and there was a significantly higher number of male subjects in the eosinophilic group $(p=0.003)$. Both groups comprised subjects older than 65 years. Heart failure was close to two-fold higher in the non-eosinophilic group. Table 1 shows the demographics, co-morbidities and $\mathrm{CBC}$ values of both groups on admission to outpatients.

The non-eosinophilic group showed a significantly higher leukocyte count, and neutrophil percentage than the eosinophilic group. In the eosinophilic group lymphocytes, eosinophil percentage, and hemoglobin were all significantly higher (for all parameters $p<$ 0.001). Platelets, MPV, and PLT/MPV values measured on admission were similar in both groups. Biochemical parameters such as blood glucose, and blood urea nitrogen were significantly higher in the noneosinophilic group.

The neutrophil lymphocyte ratio (NLR) was significantly higher $(>5)$ in the non-eosinophilic group compared with the eosinophilic group $(<3)$. Although CRP values were two times higher than normal there were no significant differences between the two groups (Table 1).

When the re-admission of patients with acute exacerbations was evaluated, 990 patients $(66 \%)$ were re-admitted to hospital in the first 28 days. While the hospital re-admission rate was $60 \%$ in the noneosinophilic group, it was $40 \%$ in the eosinophilic group. Table 2 shows demographics, comorbidities and inflammatory markers in groups with hospital readmission and with no readmission.

Also PLT/MPV ratio and CRP was found to be higher in the readmission group. Hospital re-admission of patients with peripheral blood eosinophilia $\leq 2 \%$ NLR $\geq 4.50$ is significantly higher compare to patients with peripheral blood eosinophilia $>2 \%$ and NLR $<4.50$. (OR, 1.71; 95\% Cl, 1.27-2.29; $\mathrm{p}<0.001$ ) (Figure 2).

In the case of re-admissions $51 \%$ of the noneosinophilic group were hospitalized, whereas $12 \%$ were hospitalized in the eosinophilic group. Intensive care hospitalization was close to 2-fold higher in the non-eosinophilic group compared with the eosinophilic group (3.0\% and $1.7 \%$ respectively).

\section{DISCUSSION}

In this study, the frequency of eosinophilic exacerbations (peripheral blood eosinophils $>2 \%$ ) in outpatient COPD exacerbations was found to be $42 \%$. NLR was significantly higher in the non-eosinophilic group while no significant difference in the inflammatory markers, MPV, PLT/MPV and CRP, was observed between the two groups. The rate of re-admission during the first 28 days of initial admission was significantly higher in patients with a noneosinophilic exacerbation, compared to patients with an eosinophilic attack. The hospital re-admissions were increased 1.7 times when the NLR value was 4.5 or higher in patients with COPD. In addition, the NLR value of those patients admitted to intensive care was about two times greater than the remaining admitted patients. 
Table 1. Demographics, comorbidities, hemogram and biochemistry values of COPD patients with either eosinophilic or noneosinophilic exacerbations on admission to out-patients

\begin{tabular}{|c|c|c|c|}
\hline Variables & Group 1, Eosinophilic & Group 2, Non-eosinophilic & $\mathbf{p}$ \\
\hline Number of patients, $\mathrm{n}(\%)$ & $633(42)$ & $857(58)$ & 0.002 \\
\hline Male, n (\%) & $439(69)$ & $530(62)$ & 0.003 \\
\hline Age, year, mean $( \pm S D)$ & $66 \pm 11$ & $69 \pm 11$ & 0.001 \\
\hline \multicolumn{4}{|l|}{ Co-morbid diseases, $n(\%)$} \\
\hline Diabetes mellitus & $12(1.9)$ & $20(2.3)$ & 0.56 \\
\hline Congestive heart failure & $83(13.1)$ & $148(17.3)$ & 0.028 \\
\hline Arrhythmia & $3(0.5)$ & $3(0.4)$ & 0.70 \\
\hline Coronary artery disease & $32(5.1)$ & $29(3.4)$ & 0.10 \\
\hline Hypertension & $45(7.1)$ & $35(4.1)$ & 0.10 \\
\hline \multicolumn{4}{|l|}{ Hemogram values } \\
\hline Leucocyte count, $10^{9} \mathrm{~L}$ & $8.4(6.9-10.3)$ & $10.2(7.9-13.1)$ & 0.001 \\
\hline Neutrophil, \% & $65(57-71)$ & $75(68-83)$ & 0.001 \\
\hline Monocyte, \% & $7.4(5.9-9.1)$ & $6.9(5.0-9.0)$ & 0.001 \\
\hline Lymphocyte, \% & $21.6(16.6-28.2)$ & $14.5(9.5-20.7)$ & 0.001 \\
\hline Eosinophil, \% & $3.23(2.50-4.60)$ & $0.96(0.51-1.40)$ & 0.001 \\
\hline Basophil, \% & $0.67(0.40-1.14)$ & $0.50(0.27-1.00)$ & 0.001 \\
\hline Erytrocyte count, $10^{12} \mathrm{~L}$ & $4.6(4.2-5.0)$ & $4.6(4.1-5.00)$ & 0.19 \\
\hline Hemoglobin, g/dL & $13.1(11.8-14.5)$ & $12.9(11.7-14.3)$ & 0.03 \\
\hline Hematocrite, $\%$ & $39.7(35.9-43.3)$ & $39.0(35.4-42.9)$ & 0.07 \\
\hline$M C V, f L$ & $86(83-90)$ & $86(82-90)$ & 0.40 \\
\hline Platelet count, $10^{9} \mathrm{~L}$ & $245(207-306)$ & $247(196-310)$ & 0.66 \\
\hline MPV, fL & $8.2(7.6-9.0)$ & $8.2(7.6-9.0)$ & 0.84 \\
\hline PLT/MPV & $30.0(23.1-38.5)$ & $30.0(23.6-38.7)$ & 0.61 \\
\hline NLR & $2.96(2.09-4.27)$ & $5.1(3.35-8.52)$ & 0.000 \\
\hline $\mathrm{CRP}, \mathrm{mg} / \mathrm{dL}$ & $9(3-23)$ & $10(3-36)$ & 0.05 \\
\hline \multicolumn{4}{|l|}{ Biochemistry values } \\
\hline Blood glucose, mg/dL & $109(97-141)$ & $126(105-167)$ & 0.001 \\
\hline $\mathrm{BUN}, \mathrm{mg} / \mathrm{dL}$ & $22(16-36)$ & $25(17-39)$ & 0.02 \\
\hline Serum creatine, $\mathrm{mg} / \mathrm{dL}$ & $0.83(0.71-1.10)$ & $0.85(0.70-1.12)$ & 0.99 \\
\hline Sodium, $\mathrm{mmol} / \mathrm{L}$ & $138(135-140)$ & 137 (134-139) & 0.13 \\
\hline Potassium, mmol/L & $4.0(4.0-5.0)$ & $4.0(4.0-5.0)$ & 0.32 \\
\hline SGOT, U/L & $20(16-25)$ & $22(16-33)$ & 0.001 \\
\hline SGPT, U/L & $15(10-20)$ & $16(11-24)$ & 0.003 \\
\hline Albumin, g/dL & $3.4(3.1-3.7)$ & $3.3(3.0-3.7)$ & 0.12 \\
\hline
\end{tabular}

\section{Type of COPD Exacerbations and Peripheral Blood Eosinophilia}

Despite optimal treatment regimes, acute exacerbations are a major problem for many people living with COPD. Following recovery from a COPD attack, preexacerbation levels of lung function and exercise ability may not return completely. As such, an acute exacerbation accelerates disease progression and mortality. Clinical studies indeed report a higher mortality rate in patients admitted to hospital with an acute exacerbation of COPD (23).

The most common cause of exacerbation is a tracheobronchial infection (50-70\%), while in 30\% an etiology cannot be determined (24). Although reported exacerbations are typically neutrophilic inflammation, eosinophilic inflammation can be seen in as high as 
Table 2. Demographics and inflammatory marker values of hospital re-admission

\begin{tabular}{|c|c|c|c|}
\hline Variables & Hospital readmission & Hospital readmission absent & $\mathbf{p}$ \\
\hline Number of patients, $\mathrm{n}(\%)$ & $990(66)$ & $500(34)$ & 0.002 \\
\hline Male, \% & 66.5 & 62.2 & 0.10 \\
\hline Age, year, mean (SD) & $68(10.9)$ & $67(11.6)$ & 0.27 \\
\hline \multicolumn{4}{|l|}{ Laboratory } \\
\hline Leucocyte count, $10^{9} \mathrm{~L}$ & $10.5(4.9)$ & $9.3(3.6)$ & 0.001 \\
\hline MPV, fL & $8.28(1.02)$ & $8.35(0.95)$ & 0.27 \\
\hline PLT/MPV & $32.89(13.98)$ & $31.36(12.15)$ & 0.02 \\
\hline NLR & $4.30(2.78-7.07)$ & $3.48(2.26-5.44)$ & 0.001 \\
\hline $\mathrm{CRP}, \mathrm{mg} / \mathrm{dL}$ & $11.5(3.5-37.5)$ & $8.0(3.0-16)$ & 0.05 \\
\hline \multicolumn{4}{|l|}{ Co-morbidity, n (\%) } \\
\hline Diabetes mellitus & $21(2.1)$ & $11(2.2)$ & 0.31 \\
\hline Congestive heart failure & $153(15.5)$ & $78(15.6)$ & 0.94 \\
\hline Arrhythmia & $5(0.5)$ & $1(0.2)$ & 0.21 \\
\hline Coronary artery disease & $36(3.6)$ & $25(5.0)$ & 0.92 \\
\hline Hypertension & $49(4.9)$ & $31(6.2)$ & 0.38 \\
\hline \multicolumn{4}{|l|}{$2 \% \leq$ ve NLR $\geq 4.50, n$} \\
\hline$N L R \geq 4.50$ & 368 & 126 & $<0.001$ \\
\hline $\mathrm{NLR}<4.50$ & 229 & 134 & $<0.001$ \\
\hline \multicolumn{4}{|l|}{$2 \%>$ ve $N L R<4.50, n$} \\
\hline$N L R \geq 4.50$ & 90 & 46 & 0.27 \\
\hline $\mathrm{NLR}<4.50$ & 303 & 194 & 0.27 \\
\hline
\end{tabular}

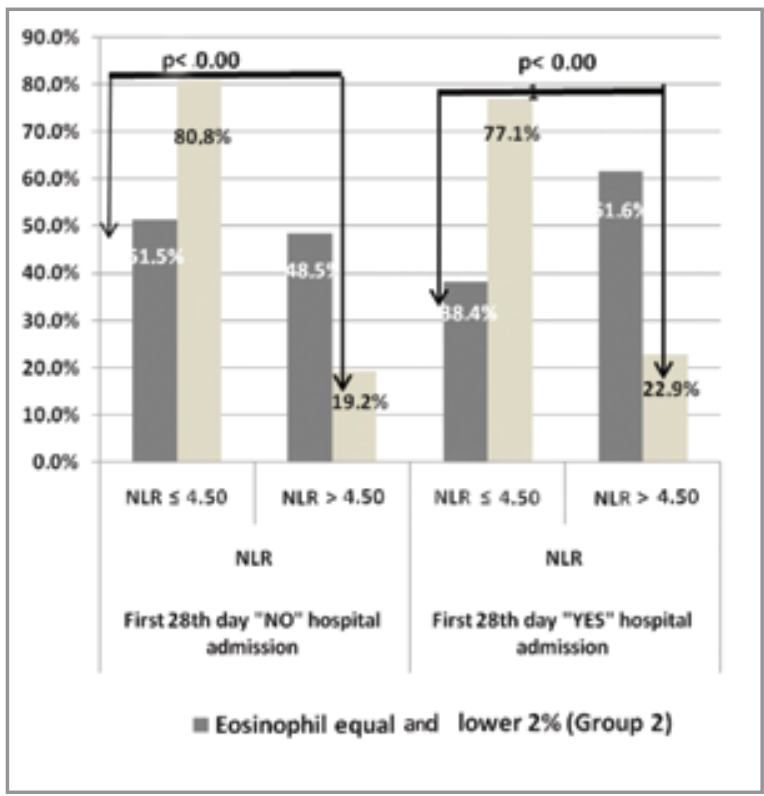

Figure 2. The neutrophil lymphocyte ratio (NLR) in patients with re-admissions and not re-admitted in the non-eosinophilic group compared in the eosinophilic group.
$45 \%$ of cases $(6-8,20)$. Eosinophilia has even been shown to exist in stable COPD patients (6). The role of eosinophilic inflammation in COPD is still controversial. There is a reportedly better response to inhaled and oral corticosteroids in these patients, and the number of exacerbations and hospital re-admissions are less (9). On the other hand, one study showed that an increase in blood eosinophils in COPD increased mortality (25). Bafedhel and co-workers demonstrated that the best cut-off value for peripheral blood eosinophilia is $2 \%$, reflecting sputum eosinophilia and eosinophilic inflammation (20). In their study, peripheral eosinophilia ( $>2 \%$ ) was detected in $49 \%$ of 109 patients admitted with COPD exacerbations (7). Similarly, in this study, eosinophilic inflammation (peripheral blood eosinophil count $>2 \%$ ) was observed in $42 \%$ of exacerbations. In the study by Bafedhel et al., ambulatory COPD patients were followed up for one year following an exacerbation. Sputum eosinophilia was detected in $28 \%$ of attacks. Interestingly they found that eosinophilic inflammation following an exacerbation was present in those patients where eosinophilic inflammation was observed in a stable period $(\mathrm{OR}, 2.7 ; 95 \% \mathrm{Cl}, 1.3-5.7)$ 
(20). Disease reportedly has a different course according to the inflammation phenotype. Accordingly, the response to standard therapy is less and late in neutrophilic inflammation compared to patients with eosinophilic inflammation. Also, the duration of hospitalization stay has been shown to be longer (4). In the present study the majority of ambulatory patients that presented with an acute exacerbation of COPD were neutrophilic, with a high blood leukocyte count, neutrophil percentage, and NLR. Re-admissions were statistically higher in the neutrophilic group compared with the eosinophilic group. Hospitalizations of these patients to the chest diseases clinic, intensive care and emergency services at re-admission suggests that the neutrophilic or non-eosinophilic group have a more serious presentation than the eosinophilic group.

\section{CRP, NLR, MPV, PLT/MPV}

CRP is the most well known inflammatory biomarker and it increases in most cases of infection, inflammation and tissue damage. CRP levels have been shown to increase the most in the neutrophilic group, but levels are also high in the stable period of COPD patients compared with healthy people $(4,15)$. In Hurst et al.'s study on 36 biomarkers, including CRP, CRP was found to be $4 \mathrm{mg} / \mathrm{mL}$ in the stable period of COPD while it was significantly higher $(15.6 \mathrm{mg} / \mathrm{mL})$ during an exacerbation. They concluded that CRP itself is not meaningful in an attack, but when CRP $\geq 8 \mathrm{mg} / \mathrm{mL}$ (95\% specificity and $57 \%$ sensitivity for an exacerbation diagnosis) is found together with a major symptom (increasing dyspnea, sputum volume, or purulence) the diagnosis is more meaningful, but still does not reflect the severity of the attack (26).

In the present study, CRP was higher in patients readmitted in the first month admission $(>8)$ and was similar in the eosinophilic and non-eosinophilic group. In those patients who were not re-admitted there was a borderline significant difference between the two groups.

While total WBC and neutrophil increases, and lymphocytopenia are observed in inflammation caused by bacterial infections, an increase in NLR is said to be more meaningful than leukocytosis, lymphopenia, and CRP increases alone (27). Terradas et al.'s study on patients with bacteremia showed that a lower eosinophil count and a higher NLR $(>7)$ were independent risk factors for mortality (28). Gunay et al. showed that in patients with COPD, NLR was elevated more in an exacerbation, but was also high in the stable period when compared with healthy people. In one study in which exacerbations were not identified as eosinophilic or non-eosinophilic, NLR was identified as an average of 4.28 , but there was no correlation with the severity of the disease (15). Gocmen et al. investigated the relationship between the severity of COPD and NLR and they found that $\mathrm{NLR}$ had a positive correlation with arterial $\mathrm{PaCO}_{2}$ and a negative correlation with $\mathrm{pH}$ and $\mathrm{FEV}_{1} / \mathrm{FVC}(\mathrm{p}=$ $0.006, p=0.007$, respectively) (29). In a study similar to ours where patients with COPD exacerbations were enrolled according to their ICD coding, they similarly found that NLR was significantly higher in those patients who died while in hospital, or who were admitted to ICU, compared to those patients who were admitted to the general ward (30).

In Peng et al.'s study, NLR was found to be high, both during the exacerbation and in the stable period, and they found a positive correlation between the severity of the attack and NLR (4).

In the present study, NLR was higher in the noneosinophilic group than the eosinophilic group. In the case of re-admissions, NLR values increased according to the severity of COPD attack in the non-eosinophilic group. Intensive care admission of patients with the highest NLR values was higher by nearly one and a half times than the eosinophilic group. Assessing the presence of peripheral eosinophilia and a thorough examination of COPD exacerbations, including ascertaining the NLR values, may help to indicate the severity of infectious and inflammatory exacerbations of COPD.

MPV, an indicator of platelet activation, is another inflammatory marker (22). The relationship with COPD and MPV is controversial. Wang and coworkers have shown a negative correlation between high WBC and CRP (22). In Gunay et al.'s study, MPV was shown to significantly decrease in acute exacerbations relative to the stable period of COPD patients (15).

PLT/MPV, as with MPV, increases in myocardial infarction, anemia, deep vein thrombosis, infective endocarditis, and hepatocellular carcinoma (30). In the present study MPV and PLT/MPV showed no correlation with the eosinophilic and non-eosinophilic group. MPV levels did not correlate with re-admission rates, but PLT/MPV was shown to be elevated in relation to increased re-admission. 


\section{Limitations}

There were some limitations in this study. Firstly, it was a retrospective study. Nonetheless, important clinical data was obtained in a large number of patients with COPD exacerbations according to their eosinophilic and non-eosinophilic inflammation type. Secondly, we did not know the GOLD stage because of the absence of spirometry values on the online system. Lastly, this study was carried out at a single center. However, our study was conducted at a specific chest diseases teaching center and revealed meaningful information for physicians in clinical practice, as well as pointing to a need for further clinical studies. Our results cannot be generalized for all patients. The strength of this study is that all data was collected on an electronic hospital data-based system and was protected from entering data error.

\section{CONCLUSION}

Assessing the NLR in hemogram values in patients admitted with exacerbations of COPD can provide important information for physicians. Nearly half of these patients may be eosinophilic (peripheral eosinophilia $>2 \%$ ). Within the first month, re-admissions may be less likely in COPD patients with peripheral eosinophilia and a NLR $<4.50$. However in patients with a NLR > 4.50, and a neutrophil dominance, the risk of re-admission and hospitalization in the first month increases. We suggest that randomized, controlled studies should be planned in the future to demonstrate whether non-eosinophilic COPD patients with a NLR greater than 4.50 may be at a higher risk of re-admission within the first month of outpatient admission. This may be crucial for making decisions on the type of treatment and the extent of follow-up for these patients.

\section{REFERENCES}

1. Singh JM, Palda VA, Stanbrook MB, Chapman $K R$. Corticosteroid therapy for patients with acute exacerbations of chronic obstructive pulmonary disease: a systematic review. Arch Intern Med 2002;162:2527-36.

2. Seemungal TA, Donaldson GC, Paul EA, Bestall JC, Jeffries DJ, Wedzicha JA. Effect of exacerbation on quality of life in patients with chronic obstructive pulmonary disease. Am J Respir Crit Care Med 1998;157:1418-22.

3. Wilkinson TM, Donaldson GC, Hurst JR, Seemungal TA, Wedzicha JA. Early therapy improves outcomes of exacerbations of chronic obstructive pulmonary disease. Am J Respir Crit Care Med 2004;169:1298-303.
4. Gao P, Zhang J, He X, Hao Y, Wang K, Gibson PG. Sputum inflammatory cell-based classification of patients with acute exacerbation of chronic obstructive pulmonary disease. PLoS One 2013;31:e57678.

5. Saetta M, Di SA, Maestrelli P, Turato G, Ruggieri MP Roggeri $A$, et al. Airway eosinophilia in chronic bronchitis during exacerbations. Am J Respir Crit Care Med 1994; 150:1646-52.

6. Kitaguchi Y, Komatsu Y, Fujimoto K, Hanaoka M, Kubo K. Sputum eosinophilia can predict responsiveness to inhaled corticosteroid treatment in patients with overlap syndrome of COPD and asthma. Int I Chron Obstruct Pulmon Dis 2012;7:283-9.

7. Bafadhel M, McKenna S, Terry S, Mistry V, Pancholi M, Venge $P$, et al. Blood eosinophils to direct corticosteroid treatment of exacerbations of chronic obstructive pulmonary disease: a randomized placebo-controlled trial. Am J Respir Crit Care Med 2012;186:48-55.

8. Brightling CE, Monteiro W, Ward R, Parker D, Morgan MD, Wardlaw AJ, et al. Sputum eosinophilia and short-term response to prednisolone in chronic obstructive pulmonary disease: a randomised controlled trial. Lancet 2000;356:1480-5.

9. Siva $R$, Green $R H$, Brightling $C E$, Shelley $M$, Hargadon $B$, McKenna $S$, et al. Eosinophilic airway inflammation and exacerbations of COPD: a randomised controlled trial. Eur Respir J 2007;29:906-13.

10. Li MX, Liu XM, Zhang XF, Zhang JF, Wang WL, Zhu Y. Prognostic role of neutrophil-to-lymphocyte ratio in colorectal cancer: a systematic review and meta-analysis. Int J Cancer 2014;134:2403-13.

11. Tamhane UU, Aneja S, Montgomery D, Rogers EK, Eagle $K A$, Gurm HS. Association between admission neutrophil to lymphocyte ratio and outcomes in patients with acute coronary syndrome. Am J Cardiol 2008;102:653-7.

12. Iliaz S, Iliaz R, Ortakoylu G, Bahadir A, Akbaba Bagci B, Caglar E. Value of neutrophil/lymphocyte ratio in the differential diagnosis of sarcoidosis and tuberculosis. Ann Thorac Med 2014;9:232-5.

13. Kayrak M, Erdoğan HI, Solak Y, Akilli H, Gül EE, Yildirim O, et al. Prognostic value of neutrophil to lymphocyte ratio in patients with acute pulmonary embolism: a restrospective study. Heart Lung Circ 2014;23:56-62.

14. Sarraf KM, Belcher E, Raevsky E, Nicholson AG, Goldstraw $P$, Lim E. Neutrophil/lymphocyte ratio and its association with survival after complete resection in non-small cell lung cancer. J Thorac Cardiovasc Surg 2009; 137:425-8.

15. Günay E, Sarınç Ulaşlı S, Akar O, Ahsen A, Günay $S$, Koyuncu $T$, et al. Neutrophil-to-lymphocyte ratio in chronic obstructive pulmonary disease: a retrospective study. Inflammation 2014;37:374-80.

16. Sorensen AK, Holmgaard DB, Mygind $L H$, Johansen J, Pedersen C. Neutrophil-to-lymphocyte ratio, calprotectin and YKL-4O in patients with chronic obstructive pulmonary disease: correlations and 5-year mortality- a cohort study. Journal of Inflammation 2015;12:20. 
17. Global Initiative for Chronic Obstructive Lung Disease. Global strategy for diagnosis, management, and prevention of COPD Updated 2012. Available: http://www. goldcopd. org.

18. American Thoracic Society, European Respiratory Society Task Force. Standards for the Diagnosis and Management of Patients with COPD. Version 1.2. New York, NY: American Thoracic Society; 2004. http://www.thoracic. org/go/copd

19. Anthonisen NR, Manfreda J, Warren CP, Hersfield ES, Harding GK, Nelson NA. Antibiotic therapy in exacerbations of chronic obstructive pulmonary disease. Ann Intern Med 1987; 106:196-204.

20. Bafadhel M, McKenna S, Terry S, Mistry V, Reid C, Haldar $P$, et al. Acute exacerbations of chronic obstructive pulmonary disease: identification of biologic clusters and their biomarkers. Am J Respir Crit Care Med 2011; 184:66271.

21. Yoon NB, Son C, Um SJ. Role of the neutrophil-lymphocyte count ratio in the differential diagnosis between pulmonary tuberculosis and bacterial community-acquired pneumonia. Ann Lab Med 2013;33:105-10.

22. Wang RT, Li JY, Cao ZG, Li Y. Mean platelet volume is decreased during an acute exacerbation of chronic obstructive pulmonary disease. Respirology 2013;18:12448.

23. Connors AF $\mathrm{Jr}$, Dawson NV, Thomas C, Harrell FE Jr, Desbiens N, Fulkerson WI, et al. Outcomes following acute exacerbation of severe chronic obstructive lung disease. The SUPPORT investigators (Study to Understand Prognoses and and Preferences for Outcomes and Risks of Treatments). Am J Respir Crit Care Med 1996;154:959-67.
24. Sapey E, Stockley RA. COPD exacerbations 2: Aetiology. Thorax 2006;61:250-8.

25. Hospers JJ, Schouten JP, Weiss ST, Rijcken B, Postma DS. Asthma attacks with eosinophilia predict mortality from chronic obstructive pulmonary disease in a general population sample. Am J Respir Crit Care Med 1999; 160:1869-74.

26. Hurst JR, Donaldson GC, Perera WR, Wilkinson TM, Biello $J A$, Hagan GW, et al. Use of plasma biomarkers at exacerbation of chronic obstructive pulmonary disease. Am J Respir Crit Care Med 2006; 174:867-74.

27. De Jager $C P$, van Wijk $P T$, Mathoera $R B$, de JonghLeuvenink J, van der Poll T, Wever PC. Lymphocytopenia and neutrophil-lymphocyte count ratio predict bacteremia better than conventional infection markers in an emergency care unit. Crit Care 2010;14:R192.

28. Terradas R, Grau S, Blanch J, Riu M, Saballs P, Castells X. Eosinophil count and neutrophil-lymphocyte count ratio as prognostic markers in patients with bacteremia: a retrospective cohort study. PLoS One 2012;7:e42860.

29. Göçmen H, Çoban H, Yıldız A, Ursavaş A, Coşkun $F$, Ediger $D$. Is there any correlation between serum CRP level and haematological parameters with severity of disease in acute exacerbation of COPD? Respiratory Diseases 2007;18:141-7.

30. Soyalıç H, Somuk BT, Doğru S, Gürbüzler L, Göktaş G, Eyibilen A. Evaluation of mean platelet volume and its ratio over platelet count in children with obstructive sleep apnea syndrome. Journal of Ear, Nose, and Throat 2015;25:16-21. 